\title{
Atypical mycobacteria in a superficial femoral artery occlusion
}

\author{
C Determann, ${ }^{1}$ AT Hill, ${ }^{2}$ H Monaghan, ${ }^{3}$ SCA Fraser ${ }^{1}$ \\ 1Department of Vascular Surgery, Royal Infirmary of Edinburgh, Edinburgh, UK; \\ ${ }^{2}$ Department of Respiratory Medicine, Royal Infirmary of Edinburgh, Edinburgh, UK; \\ ${ }^{3}$ Department of Laboratory Services (Pathology), Royal Infirmary of Edinburgh, Edinburgh, UK \\ Correspondence to Mr Simon Charles Fraser, simon.fraser@luht.scot.nhs.uk
}

\begin{abstract}
Summary
There is indirect evidence that atherosclerosis may occur in association with bacterial infection. The authors report the case of a young woman who presented with right calf claudication caused by a short occlusion of the superficial femoral artery. Histological examination of the excised segment of artery revealed atheroma and atypical mycobacteria within adventitial caseating granulomata. The possible causes are discussed.
\end{abstract}

\section{BACKGROUND}

This is the first proven case of mycobacteria infecting atherosclerotic artery.

\section{CASE PRESENTATION}

A 42-year-old woman presented with right calf claudication at $200 \mathrm{~m}$, which resolved on resting. She was an occasional smoker, was non-diabetic and had no family history of arterial disease. Five years previously she had sustained a ligamentous injury to her right knee which had eventually been treated by physiotherapy. Right sided pulses were absent beyond a normal femoral pulse. The anklebrachial pressure index of the left leg was 1.0 and the right leg 0.6.

\section{INVESTIGATIONS}

A duplex ultrasound scan identified a $3 \mathrm{~cm}$ long occlusion in the adductor segment of the superficial femoral artery (SFA) with three vessel run-off, and no other lesions elsewhere. Magnetic resonance angiogram confirmed the ultrasound appearance in the right leg and normal arteries in the left. Her random cholesterol was measured at that stage and found to be $9 \mathrm{mmol} / \mathrm{l}$.

\section{TREATMENT}

Three months later, her walking distance had diminished so a bypass of the occluded segment was planned, rather than angioplasty, which was considered to offer a lesser chance of long-term success. At operation, the occluded segment of SFA at the level of the adductor hiatus was unusually dilated and hard, but with macroscopically normal vessel proximal and distal to this. Because of the unusual appearance, and the bulk of a lesion in a cramped anatomical site, it was decided to remove the diseased segment to make room for an interposition graft of autologous long saphenous vein taken from the ipsilateral upper thigh.

\section{OUTCOME AND FOLLOW-UP}

The postoperative recovery was uncomplicated and subsequent graft surveillance has been satisfactory. The resected artery was sent for histological examination. This confirmed the presence of atheroma with recanalisation of the vessel. In addition caseating granulomatous inflammation in the adventitia was noted and mycobacteria, positive with Wade Fite staining, and negative with Ziehl-Neelsen staining were seen (figure 1). Subsequent tuberculin testing was strongly positive but the Quantiferon TB gold test was negative, implying the strongly positive tuberculin skin test was due to environmental mycobacteria infection. The patient was commenced on a statin postoperatively. A presumptive diagnosis of infection with an atypical environmental mycobacterium has been made and treatment commenced with rifampicin, ethambutol and clarithromycin for 24 months.

\section{DISCUSSION}

The finding of mycobacteria apparently infecting an atheromatous segment of artery has not previously been reported. The finding in this case was serendipitous because the occluded arterial segment is not usually removed, nor sent for histological examination during surgical revascularisation. It is unclear whether the presence of mycobacteria in this vessel was a primary or a secondary event. The patient had hypercholesterolaemia, and had a history of trauma to the knee, so these could have combined to accelerate atherosclerotic degeneration at a site known to be vulnerable to atherosclerotic disease. However she is young, with a history of only occasional cigarette consumption and from a high socioeconomic group.

The evidence for mycobacterial involvement in atherosclerosis relates to heat shock proteins (HSPs), ${ }^{1}$ present in healthy individuals to protect polypeptide synthesis and repair proteins that have become denatured. ${ }^{2} \mathrm{HSP} 60$ has now been found in serum and is also expressed on cell surfaces. ${ }^{3}$ It has been postulated that homology between 


\section{BMJ Case Reports}

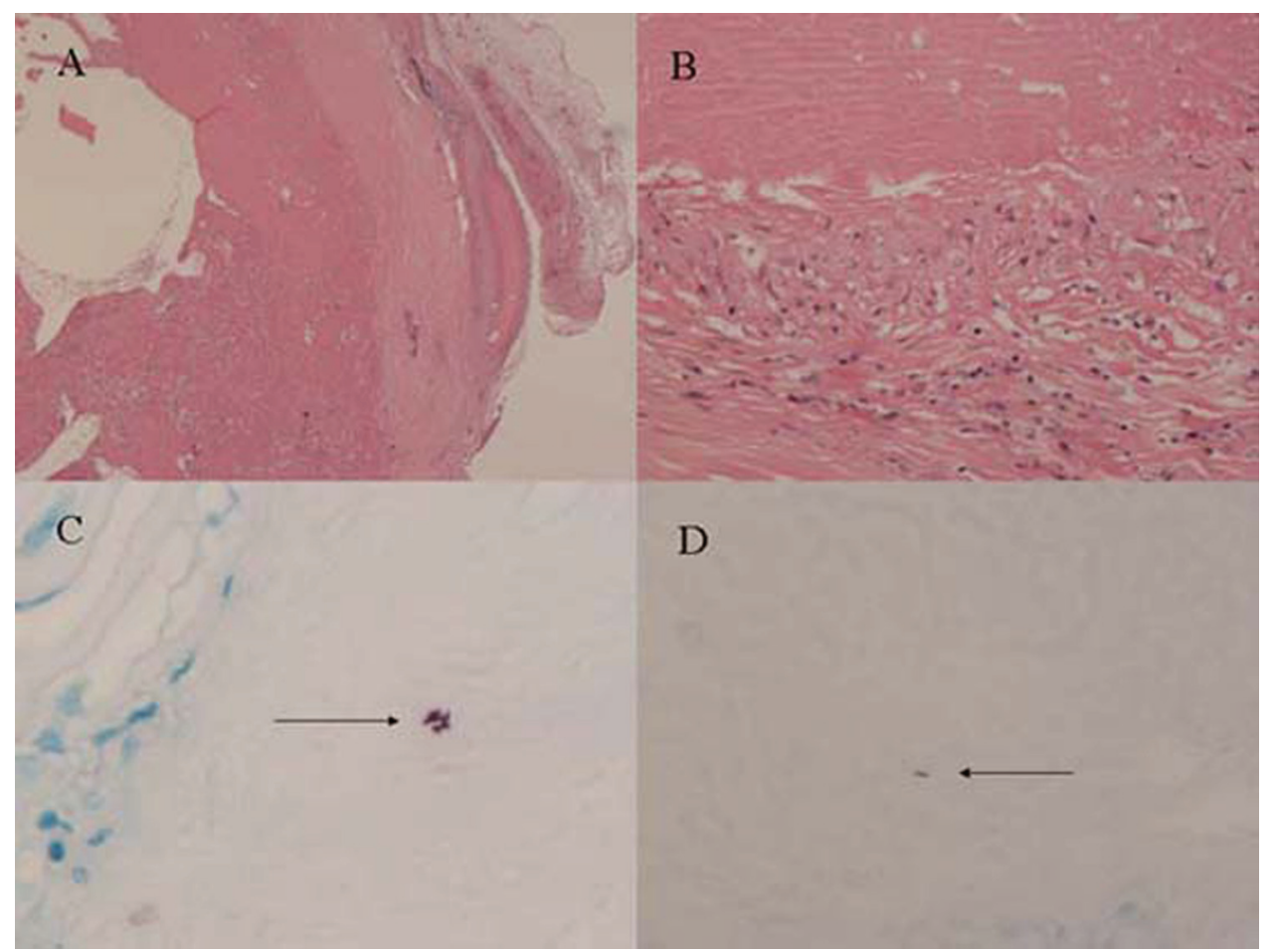

Figure 1 (A) Area of granulomatous inflammation with caseation (H\&E $\times 2$ magnification), (B) Area of granulomatous inflammation with caseation (H\&E $\times 20$ magnification), (C, D) Wade Fite staining showing atypical mycobacteria (arrowed) ( $\times 60$ magnification).

human and bacterial HSPs allows antibodies produced in response to bacterial infection to cross-react with the human HSPs on endothelial cells, provoking an inflammatory reaction and early atherosclerosis. ${ }^{4-6}$

HSP60 has been identified as localising to atherosclerotic lesions in arterial wall, HSP70 in inflammatory cells in advanced atherosclerotic disease. ${ }^{7}$ Anti-HSP65 antibodies have been found in patients with carotid plaque ${ }^{8}$ and titre levels of anti-HSP65 have been correlated to the severity of carotid lesions. ${ }^{9}$ A correlation has been reported too between anti-HSP60 antibodies and anti-Chlamydia pneumoniae antibodies. ${ }^{10}$

\section{Learning points}

- The finding of atypical mycobacteria in an isolated area of atheroma may or may not indicate a role of HSPs; however, it does raise the issue of whether biopsy of atherosclerotic lesions should accompany revascularisation more frequently.

\section{REFERENCES}

1. Lindquist S. The heat-shock response. Ann Rev Biochem 1986;55:1151-91.

2. Beckmann RP, Mizzen LE, Welch WJ. Interaction of Hsp 70 with newly synthesized proteins: implications for protein folding and assembly. Science 1990;248:850-4.

3. Xu 0, Schett G, Seitz CS, et al. Surface staining and cytotoxic activity of heat-shock protein 60 antibody in stressed aortic endothelial cells. Circ Res 1994;75:1078-85.

4. Mandal K, Jahangiri M, Xu Q. Autoimmunity to heat shock proteins in atherosclerosis. Autoimmun Rev 2004;3:31-7.

5. Wick G, Knoflach M, Xu O. Autoimmune and inflammatory mechanisms in atherosclerosis. Annu Rev Immunol 2004;22:361-403.

6. Wick G, Perschinka H, Millonig G. Atherosclerosis as an autoimmune disease: an update. Trends Immunol 2001;22:665-9.

7. Bobryshev YV, Lord RS. Expression of heat shock protein-70 by dendritic cells in the arterial intima and its potential significance in atherogenesis. J Vasc Surg 2002;35:368-75

8. Xu Q, Willeit J, Marosi M, et al. Association of serum antibodies to heatshock protein 65 with carotid atherosclerosis. Lancet 1993;341:255-9.

9. Xu $\mathbf{0}$, Kiechl S, Mayr M, et al. Association of serum antibodies to heat-shock protein 65 with carotid atherosclerosis: clinical significance determined in a follow-up study. Circulation 1999;100:1169-74.

10. Mayr M, Kiechl S, Willeit J, et al. Infections, immunity, and atherosclerosis: associations of antibodies to Chlamydia pneumoniae, Helicobacter pylori, and cytomegalovirus with immune reactions to heat-shock protein 60 and carotid or femoral atherosclerosis. Circulation 2000;102:833-9. 


\section{BMJ Case Reports}

This pdf has been created automatically from the final edited text and images.

Copyright 2011 BMJ Publishing Group. All rights reserved. For permission to reuse any of this content visit http://group.bmj.com/group/rights-licensing/permissions.

BMJ Case Report Fellows may re-use this article for personal use and teaching without any further permission.

Please cite this article as follows (you will need to access the article online to obtain the date of publication).

Determann C, Hill AT, Monaghan H, Fraser SCA. Atypical mycobacteria in a superficial femoral artery occlusion. BMJ Case Reports 2011;

10.1136/bcr.02.2011.3815, date of publication

Become a Fellow of BMJ Case Reports today and you can:

- Submit as many cases as you like

- Enjoy fast sympathetic peer review and rapid publication of accepted articles

- Access all the published articles

- Re-use any of the published material for personal use and teaching without further permission

For information on Institutional Fellowships contact consortiasales@bmjgroup.com

Visit casereports.bmj.com for more articles like this and to become a Fellow 